\title{
THE EFFECTS OF QUANTITY AND QUALITY OF DIET NITROGEN ON THE GROWTH, EFFICIENCY OF FOOD UTILIZATION, NITROGEN BUDGET, AND METABOLIC RATE OF FIFTH-INSTAR SPODOPTERA ERIDANIA LARVAE (LEPIDOPTERA: NOCTUIDAE)
}

\author{
David N. Karowe and Michael M. Martin* \\ Department of Biology, Univeristy of Michigan, Ann Arbor, MI 48109-1048, U.S.A.
}

(Received 10 January 1989; revised 30 March 1989)

\begin{abstract}
Relative growth rate and relative nitrogen accumulation rate for fifth-instar Spodoptera eridania larvae vary less than $20 \%$ on artificial diets in which protein content varies more than $250 \%$, due to compensatory adjustments in consumption rate and changes in efficiencies of food and nitrogen utilization. The substitution of zein for two-thirds of the casein in a diet containing $26.0 \%$ protein results in a $25 \%$ decrease in both relative growth and nitrogen accumulation rates, due to reduced values of relative consumption rate, relative nitrogen consumption rate, approximate digestibility, approximate digestibility of nitrogen and efficiency of conversion of digested nitrogen. Although larval growth rate is relatively independent of diet nitrogen, larval composition is highly dependent upon both nitrogen quantity and quality. As diet nitrogen increases, larval nitrogen content increases and fat content decreases. Larvae on diets containing a mixture of casein and zein produce 3.5-3.9 times as much uric acid and respire at rates significantly higher than larvae on diets containing the same total amount of protein but lacking zein. Thus, there is a measurable metabolic cost associated with processing low quality protein. We conclude, however, that elevated metabolic rates of larvae on diets containing nutritionally unbalanced protein are not the cause of reduced growth rates. On these diets, growth is limited by an amino acid present in limiting quantities, and the elevated metabolic rate is due, at least in part, to increased synthesis of uric acid. Finally, we discuss the possibility that variation in amino acid profiles across host plant species might be a factor favouring specialization in insect herbivores.
\end{abstract}

Key Word Index: Southern armyworm, Spodoptera eridania, growth, nutritional indices, food utilization, nitrogen budget, uric acid production, respiration rate, metabolic cost

\section{INTRODUCTION}

The importance of dietary nitrogen as a factor influencing both the fitness of individual herbivorous insects and the dynamics of insect populations has been extensively documented (Slansky and Feeny, 1977; McNeill and Southwood, 1978; Mattson, 1980; Lee et al., 1983; Scriber, 1984). According to Scriber (1984), the literature contains "at least 115 different studies in which insect damage, growth, fecundity, or numbers increased with increased plant nitrogen". In the same review, however, Scriber notes that "at least 44 studies with insects and a few with mites indicate a decrease in herbivore population or damage with high nitrogen concentrations or an increase in insect populations with low nitrogen". Moreover, studies have shown negative correlations between dietary nitrogen and various fitness parameters (Rodriguez $e t$ al., 1970; Hare, 1983; Horie and Watanabe, 1983; Brewer et al., 1985; Jansson and Smilowitz, 1985; Broadway and Duffey, 1986; Schroeder, 1986). Clearly the quantity of nitrogen or protein present in a food is not an infallible indicator of its capacity to support herbivore growth. Nitrogen quality must also be of critical importance.

*To whom all correspondence should be addressed.
The nutritional quality of a protein is a function of its amino acid composition. The critical importance of the amino acid composition of the diet to growth and reproduction in insects has been elegantly documented in studies of several species of aphids (Dadd and Krieger, 1968; Retnakaran and Beck, 1968; van Emden, 1972; Carter and Cole, 1977), adult mosquitoes (Briegel, 1985), and larvae of the commercial silkworm moth Bombyx mori (Horie and Inokuchi, 1978; Horie and Watanabe, 1983). Schroeder and Malmer (1980) have also stressed the importance of the amino acid composition of leaf proteins to the growth of insect folivores. Surveys of a wide variety of plant species have revealed differences in total leaf protein content and composition that are of potential nutritional significance (Autret, 1970; Watson and Creaser, 1975; Yeoh and Watson, 1982; Yeoh et al., 1984, 1986).

It has been suggested that a nutritionally unbalanced protein might reduce an herbivore's growth rate by imposing a metabolic load (Slansky and Scriber, 1985; Schroeder, 1986). This idea is expressed succinctly by Slansky and Scriber (1985): “... in response to nutrient imbalances in its food a larva may exhibit increased catabolism and excretion of the over-abundant nutrients (e.g. excess amino acids). The larva may thus be able to grow, but its net 
growth efficiency is usually low and its growth rate showed". This argument assumes that since the efficiency of conversion of digested food (net growth efficiency) reflects the allocation of assimilated food to growth vis-a-vis energy metabolism, any metabolic cost associated with processing assimilated food results in the diversion of assimilated nutrients from growth into the pathways of energy metabolism. Schroeder (1986) has pointed out that even a high quality protein when present in excess could be more of a liability than an asset, since "added protein, contrary to providing useful nutrients, actually places a metabolic load on the larvae".

In this study we have addressed the extent to which growth and metabolic rates of the southern armyworm, Spodoptera eridania, are influenced by the quantity and quality of nitrogen incorported into an artificial diet. S. eridania is a highly polyphagous species that can achieve high growth rates on a diverse array of plant species (SoO Hoo and Franenkel, 1966). We have conducted accurate measurements of growth rate, efficiency of food utilization, carcass composition, the nitrogen budget, uric acid production, and respiration rate of fifth-instar $S$. instar larvae on diets containing various combinations of casein (a high quality protein) and zein (a low quality protein), a mixture of 10 essential amino acids, or a mixture of 2 non-essential amino acids. We have addressed the following questions: (1) Do $S$. eridania larvae stabilize their growth rates on artificial diets that differ with respect to the quantity and quality of the nitrogen sources present? (2) What is the relative importance of nitrogen quantity vs quality in determining larval growth rate? (3) Do larvae reared on diets with different sources of nitrogen differ with respect to their protein and lipid composition? (4) Is there a metabolic cost associated with processing a diet that is unusually high in nitrogen or one that contains a nutritionally unbalanced nitrogen source? (5) Do imposed metabolic processing costs cause reduced growth rates? We conclude by discussing the possibility that nutritionally unbalanced foliar proteins might not only constitute a general 'barrier' to herbivory (sensu Southwood, 1973), but also may select for specialization in insect herbivores.

\section{MATERIALS AND METHODS}

\section{Insects and artificial diets}

Eggs of S. eridania (Lepidoptera: Noctuidae) were obtained from the FMC Corporation (Princeton, N.J.), where cultures had been maintained on a casein-based artificial diet for approx. 4 yr (about 24 generations; W. Fisher, personal communication).

The artificial diets were prepared by combining varying amounts of a nitrogen source (casein, zein, a mixture of 10 essential amino acids, or a mixture of 2 non-essential amino acids) with the following standard diet mixture: sucrose $(8.0 \mathrm{~g})$, ascorbic acid $(1.6 \mathrm{~g})$, stabilized wheat germ $(8.4 \mathrm{~g}), \alpha$-cellulose $(3.0 \mathrm{~g})$, methylparaben $(0.3 \mathrm{~g})$, isolecithin $(0.4 \mathrm{~g}$ in $2.0 \mathrm{ml}$ of $95 \%$ ethanol), vitamin $\mathrm{E}$ is linseed oil (1.75 $\mathrm{ml}$ of a $2.3 \%$ solution), and a vitamin/mineral mixture $(30 \mathrm{ml})$. The vitamin $/$ mineral mixture was prepared by dissolving or suspending Bioserv Salt
Mix $(40.0 \mathrm{~g})$, choline chloride $(10.0 \mathrm{~g})$, potassium sorbate $(7.5 \mathrm{~g})$, calcium pantothenate $(2.5 \mathrm{~g})$, niacin $(2.5 \mathrm{~g})$, riboflavin $(1.25 \mathrm{~g})$, streptomycin $(1.0 \mathrm{~g})$, thiamine hydrochloride $(0.6 \mathrm{~g})$, pyridoxine hydrochloride $(0.6 \mathrm{~g})$, folic acid $(0.6 \mathrm{~g})$, and biotin $(0.05 \mathrm{~g})$ in $750 \mathrm{ml}$ of water. The essential amino acid mixture contained 1.00 part each (by weight) of histidine, tryptophan and methionine, 1.66 parts each of isoleucine and threonine, 2.00 parts each of phenylalanine, valine and arginine, 2.33 parts of lysine, and 2.66 parts of leucine. The non-essential amino acid mixture contained equal weights of aparagine and glutamic acid. Diet 1 consisted of the standard diet mixture with no additional sources of nitrogen added. This diet is not protein-free, however, since wheat germ contains $25 \%$ protein. Thus, each diet contains $2.1 \mathrm{~g}$ of wheat germ protein. Cascin $(2.1,4.2,6.3,8.4$, $10.5,12.6$ or $17.7 \mathrm{~g}$ ) was added to the standard diet mixture to prepare diets $2 \mathrm{C}-8 \mathrm{C}$, respectively. Diet $4 \mathrm{CZ}$ was prepared by adding $2.1 \mathrm{~g}$ casein plus $4.2 \mathrm{~g}$ of zein to the standard diet mixture, whereas diet $7 \mathrm{CZ}$ was prepared by adding $6.3 \mathrm{~g}$ of casein plus $6.3 \mathrm{~g}$ of zein. Diets $7 \mathrm{CE}$ and $7 \mathrm{CN}$ were prepared by adding $6.3 \mathrm{~g}$ of casein and $6.3 \mathrm{~g}$ of the stock mixtures of essential amino acids or non-essential amino acids, respectively. Water and agar contents were adjusted such that each diet contained $82 \%$ water, and each contained $3.5 \mathrm{~g}$ of agar per $100 \mathrm{ml}$ of water.

\section{Growth rates and nutritional indices}

In order to determine 15-day growth rates, 25 newly-hatched larvae were placed individually into 25-mi polystyrene cups containing one of the artificial diets $1,2 \mathrm{C}, 3 \mathrm{C}, 4 \mathrm{C}, 5 \mathrm{C}, 6 \mathrm{C}, 7 \mathrm{C}$ or $8 \mathrm{C}$, and placed in an incubator $\left(24^{\circ} \mathrm{C}, 16 \mathrm{~h}\right.$ light $-8 \mathrm{~h}$ dark $)$. Fresh diet was provided every third day. After 15 days, all surviving larvae were starved for $2 \mathrm{~h}$ (to allow gut clearance), after which the larvae were frozen, dried at $70^{\circ} \mathrm{C}$, and weighed. Pairwise differences in final larval dry mass among the 8 diets were determined by Mann-Whitney $U$ tests, whereas pairwise differences in survivorship were determined by $\chi^{2}$ analysis after Yates correction for small expected frequencies (Sokal and Rohlf, 1981). In both cases, the Bonferroni procedure was used to adjust $\alpha$ to $0.05 / n$, where $n$ is the total number of pairwise comparisons performed (Neter et al., 1985).

Nutritional indicies were determined on fifth-instar larvae from a colony established from eggs from the FMC colony that had been maintained for 3 generations on lima beans. Immediately upon hatching, larvae were placed into $25-\mathrm{ml}$ polystyrene cups (10 larvae/cup) containing one of the 5 artificial diets $2 \mathrm{C}$, $4 \mathrm{C}, 4 \mathrm{CZ}, 7 \mathrm{C}$ or $7 \mathrm{CZ}$. Larval density was reduced to s/cup during the third and fourth instars. Immediately upon moulting to the fifth (penultimate) instar, larvae were weighed and placed individually into cups containing a preweighed amount of the same diet upon which they had fed during the first 4 instars. To the extent possible, initial larval mass was standardized across diets. The cups containing the larvae and their food were placed in an incubator $\left(24^{\circ} \mathrm{C}, 16 \mathrm{~h}\right.$ light $-8 \mathrm{~h}$ dark) until the larvae moulted to the sixth instar. Fresh diet was provided every third day, or more often if necessary. In order to maximize the accuracy of the nutritional indices, the quantity of 
food supplied was such that at least $75 \%$ was consumed by the larvae during the instar. Immediately upon moulting to the sixth instar, larvae were frozen, and larvae, frass, and uneaten food were dried for $72 \mathrm{~h}$ at $70^{\circ} \mathrm{C}$, and weighed. To provide a conversion factor for calculating the initial dry mass of the larvae, 10-20 freshly moulted fifth-instar larvae from each diet were weighed, frozen, dried for $72 \mathrm{~h}$ at $70^{\circ} \mathrm{C}$, and reweighed. The dry mass of food provided to larvae was estimated in analogous fashion, using 20 1-g samples of each diet. Larval nitrogen content at the onset of the fifth instar was determined from the larvae sacrificed to provide the larval wet-to-dry mass conversion factor.

Nutritional indices were calculated according to Waldbauer (1968). Relative rates of consumption and growth were based on the arithmetic mean of initial and final larval dry masses. All indices were calculated on a dry mass basis.

Relative growth rate

$$
=\frac{\text { larval mass gained }}{\text { average larval mass } \times \text { days }}
$$

Relative consumption rate

$$
=\frac{\text { mass of food ingested }}{\text { average larval mass } \times \text { days }}
$$

Assimilation efficiency

$$
=\frac{\text { mass of food ingested }- \text { mass of frass }}{\text { mass of food ingested }}
$$

Net growth efficiency $=$

$$
=\frac{\text { larval mass gained }}{\text { mass of food ingested - mass of frass }}
$$

Gross growth efficiency

$$
=\frac{\text { larval mass gained }}{\text { mass of food ingested }}
$$

Relative nitrogen accumulation rate

$$
=\frac{\text { nitrogen gained }}{\text { average larval nitrogen } \times \text { days }}
$$

Relative nitrogen consumption rate

$$
=\frac{\text { nitrogen ingested }}{\text { average larval nitrogen } \times \text { days }}
$$

Nitrogen assimilation efficiency $=$

$$
=\frac{\text { nitrogen ingested }- \text { nitrogen in frass }}{\text { nitrogen ingested }}
$$

Nitrogen conversion efficiency

$$
=\frac{\text { nitrogen gained }}{\text { nitrogen ingested - nitrogen in frass }}
$$

Nitrogen utilization efficiency

$$
=\frac{\text { nitrogen gained }}{\text { nitrogen ingested }}
$$

The sample size for nitrogen nutritional indices is 6 or 7 , since it was necessary to pool 2-4 larvae to provide enough material for replicate nitrogen analyses. All nitrogen nutritional indices have been corrected for uric acid content of frass and larvae. Mean values of nutritional indices for dry mass and dietary nitrogen, and of uric acid production, were compared by ANOVA. Significant pairwise differences were determined by Scheffe analysis. Where necessary, values were arcsin-square root transformed to equalize variances. Where variances could not be equalized, the significance of pairwise diffierences was determined by Mann-Whitney $U$ tests using the Bonferroni procedure with $\alpha$ adjusted to $0.05 / n$, where $n$ is the total number of pairwise comparisons performed.

\section{Chemical analyses}

The nitrogen content of artificial diet, larvae, and frass was determined by $\mathbf{K j e l d a h l}$ analysis with a Tecator Kjeltec 1030 Auto Analyzer and Digestion System (Martin and Van't Hof, 1988). Two to 4 replicates of each frass and larval sample, and 5 replicates of each diet sample, were digested at $410^{\circ} \mathrm{C}$ for $1 \mathrm{~h}$. It was necessary to pool 2-4 larvae to provide sufficient material for 2 replicate analyses.

Uric acid content of larvae and frass was determined by adapting the method of Bhattacharya and Waldbauer (1969), as described by Martin and Van't Hof (1988). Two to 4 samples were pooled to provide sufficient material for 2 replicate analyses.

Lipid and protein analyses were conducted on material prepared by grinding 3-6 whole frozen larvae under liquid nitrogen with a mortar and pestle, and drying for $24 \mathrm{~h}$ at $70^{\circ} \mathrm{C}$. Lipid content was determined by weighing dried larval powder (about $30 \mathrm{mg}$ ) before and after extraction for $3 \mathrm{~min}$ with $2 \times 3.0$-ml portions of $2: 1$ chloroform: methanol in a motor-driven tissue grinder. The defatted larval powder was separated from the extract solution by centrifugation ( $5 \mathrm{~min}, 2200 \mathrm{rpm}$ ). Protein was extracted ( $3 \mathrm{~min}$ ) from the defatted larval powder with $2 \times 2.5$ $\mathrm{ml}$ portions of cold $0.1 \mathrm{M}$ sodium hydroxide. Immediately following each extraction, the tube containing the extract was placed in a boiling water bath for $3 \mathrm{~min}$ to denature extracted proteases, then centrifuged ( $5 \mathrm{~min}, 2200 \mathrm{rpm}$ ). The supernatant solutions were combined and made up to a total volume of $5.0 \mathrm{ml}$ by the addition of $0.1 \mathrm{M}$ sodium hydroxide. Protein was determined by the Bradford (1976) technique, using bovine serum albumin as a standard.

\section{Respiration rates}

Larvae in the active feeding phase of the fifth instar were placed individually in 22-ml respirometer flasks containing $0.5 \mathrm{ml}$ of deionized distilled water in the sidearm and $0.4 \mathrm{ml}$ of $10 \%$ potassium hydroxide in the center well, and the flasks were attached to the respirometer (Gilson Model GR 14). Larval movement within flasks was minimized by placing the larvae inside plastic pipette tips that had been perforated 20 times to allow air to pass freely. After a 15-min equilibration period, oxygen consumption was measured for $1 \mathrm{~h}$ at $25^{\circ} \mathrm{C}$. At the conclusion of the measurement, larvae were frozen, dried for $72 \mathrm{~h}$ at $70^{\circ} \mathrm{C}$, and weighed. Test larvae were selected to represent as wide a range of fifth-instar masses as possible. Linear regressions of natural $\log$ of respiration rate against the natural log of larval dry weight were calculated for each diet, and the regressions were compared by ANCOVA, in order to identify signifi- 
Table 1. Amounts of nitrogen, total protein, wheat germ protein, casein, zein, essential amino acid mixture, and non-essential amino acid mixture present in diets fed Spodoptera eridania larvae in this study

\begin{tabular}{|c|c|c|c|c|c|c|c|}
\hline \multirow[b]{2}{*}{ Diet } & \multicolumn{7}{|c|}{ Content $(\%)$} \\
\hline & Nitrogen & $\begin{array}{c}\text { Total } \\
\text { protein }\end{array}$ & $\begin{array}{l}\text { Wheat } \\
\text { germ } \\
\text { protein }\end{array}$ & Casein & Zein & $\begin{array}{l}\text { Essential } \\
\text { amino acid } \\
\text { mixture }\end{array}$ & $\begin{array}{l}\text { Non-essential } \\
\text { amino acid } \\
\text { mixture }\end{array}$ \\
\hline 1 & $1.80(0.01)$ & 8.0 & 8.0 & - & - & - & - \\
\hline $2 \mathrm{C}$ & $2.63(0.04)$ & 15.0 & 7.5 & 7.5 & - & - & - \\
\hline $3 C$ & $3.43(0.01)$ & 20.9 & 7.0 & 13.9 & - & - & - \\
\hline $4 C$ & $4.19(0.16)$ & 26.0 & 6.5 & 19.5 & - & - & - \\
\hline $4 C Z$ & $4.03(0.07)$ & 26.0 & 6.5 & 6.5 & 13.0 & - & - \\
\hline $5 C$ & $4.66(0.01)$ & 30.5 & 6.1 & 24.4 & - & - & - \\
\hline $6 C$ & $5.15(0.01)$ & 34.6 & 5.8 & 28.8 & - & - & - \\
\hline $7 \mathrm{C}$ & $5.54(0.10)$ & 38.0 & 5.4 & 32.6 & - & - & - \\
\hline $7 \mathrm{CZ}$ & $5.57(0.07)$ & 38.0 & 5.4 & 16.3 & 16.3 & - & - \\
\hline $7 \mathrm{CE}$ & $5.37(0.08)$ & 21.7 & 5.4 & 16.3 & - & 16.3 & - \\
\hline $7 \mathrm{CN}$ & $4.85(0.01)$ & 21.7 & 5.4 & 16.3 & - & - & 16.3 \\
\hline $8 \mathrm{C}$ & $6.40(0.35)$ & 41.3 & 5.2 & 36.1 & - & - & - \\
\hline
\end{tabular}

Nitrogen content was measured experimentally and is reported as the mean of 3-5 replicate analyses with standard deviation in parentheses. Other values are calculated from the recipe used in preparing the diets.

cant shifts in the $y$-intercepts of the regression equations (Sokal and Rohlf, 1981).

\section{RESULTS}

Amounts of various nitrogen sources in experimental diets

The amounts of nitrogen, total protein, wheat germ protein, casein, zein, essential amino acid mixture, and non-essential amino acid mixture present in the experimental diets are summarized in Table 1. Diets with designations beginning with different numbers differ in nitrogen quantity, while diets with designations beginning with the same number differ in nitrogen quality. In the diet designations, $\mathrm{C}$ indicates the presence of casein, $Z$ of zein, $E$ of the mixture of the 10 essential amino acids, and $N$ of the mixture of the 2 non-essential amino acids.

\section{Growth and efficiency of food utilization}

Growth of $S$. eridania larvae during the first 15 days after hatching (approximately until the onset of the fifth instar) is dependent upon the amount of protein in the diet (Table 2). Growth was maximal on diets $3 \mathrm{C}, 4 \mathrm{C}$ and $5 \mathrm{C}$, that is, on diets containing between $3.4-4.7 \%$ nitrogen (20.9-30.5\% protein), but decreased significantly on diets with higher and

Table 2. Weight and survival after 15 days of Spodoptera eridania larvae fed diets of different nitrogen content

\begin{tabular}{|c|c|c|c|}
\hline \multirow[b]{2}{*}{ Diet* } & \multicolumn{2}{|c|}{ Larval dry mass } & \multirow{2}{*}{$\begin{array}{c}\text { Survivorship } \dagger \\
(\%)\end{array}$} \\
\hline & $n$ & (mg) & \\
\hline 1 & 7 & $0.9^{2}(1.8)$ & $28^{4}$ \\
\hline $2 \mathrm{C}$ & 20 & $22.6^{\text {bd }}(12.4)$ & $80^{\mathrm{b}}$ \\
\hline $3 \mathrm{C}$ & 24 & $39.2^{\mathrm{c}}(9.9)$ & $96^{b}$ \\
\hline $4 C$ & 25 & $39.2^{c}(10.7)$ & $100^{b}$ \\
\hline $5 C$ & 25 & $38.1^{\circ}(7.7)$ & $100^{\circ}$ \\
\hline $6 \mathrm{C}$ & 25 & $31.7^{a}(8.3)$ & $100^{b}$ \\
\hline $7 \mathrm{C}$ & 25 & $28.7^{d}(4.9)$ & $100^{\mathrm{b}}$ \\
\hline $8 \mathrm{C}$ & 24 & $14.6^{\mathrm{b}}(S .0)$ & $96^{b}$ \\
\hline
\end{tabular}

Means are reported with standard deviations in parentheses. Means followed by different letters are significantly different as determined by Mann-Whitney $U$ tests (larval dry mass) or $\chi^{2}$ analysis after Yates correction (survivorship), with $\alpha$ set at 0.0025 $(0.05 / 20)$ to adjust for multiple comparisons.

* Refer to Table 1 for composition of diet.

tAll trials were begun with 25 newiy-hatched larvae. lower values of dietary nitrogen. Thus, maximal growth occurs on artificial diets with dietary nitrogen levels that fall within the range of values encountered by $S$. eridania larvae in nature. Like growth, larval survivorship is also decreased on diets with nitrogen levels below $3.4 \%$. On the high-nitrogen diets, however, survivorship remains high even though growth rate is reduced.

The importance of the quantity of dietary nitrogen is also revealed by a comparison of the nutritional indices of fifth-instar larvae on diets $2 \mathrm{C}, 4 \mathrm{C}$ and $7 \mathrm{C}$ (Table 3). Both relative growth rate and final larval mass were significantly lower for larvae fed diet $7 \mathrm{C}$ than for larvae fed either $2 \mathrm{C}$ or $4 \mathrm{C}$. Although the $18 \%$ range in the relative growth rates of larvae fed diets $2 \mathrm{C}, 4 \mathrm{C}$ and $7 \mathrm{C}$ may translate into real differences in fitness, it is nonetheless relatively little variation given that these diets vary 2.1 - and 2.5 -fold in nitrogen and protein concentration, respectively. This relative stabilization in growth rate arises because of compensatory changes in consumption rate and approximate digestibility. As casein is substituted for cellulose, the digestibility of the diet necessarily increases. Thus, it is the capacity to adjust feeding rate that allows $S$. eridania larvae to minimize the effect of variation in diet protein content on growth rate.

The influence of protein quality on growth of fifth-instar $S$. eridania larvae is also apparent in Table 3. The replacement of a portion of the casein in the diet with zein results in significant decreases in final larval mass and relative growth rate and a significant increase in instar duration for larvae on diets containing $26.0 \%$ protein (diets $4 \mathrm{C}$ and $4 \mathrm{CZ}$ ). However, a similar substitution of zein for casein has no effect on these parameters for larvae on diets containing $38.0 \%$ protein (diets $7 \mathrm{C}$ and $7 \mathrm{CZ}$ ). The reduction in relative growth rate of larvae on diet $4 \mathrm{CZ}$ relative to larvae on diet $4 \mathrm{C}$ is a consequence of reductions of both relative consumption rate and growth efficiency. In contrast, neither of the latter differs between larvae on diets $7 \mathrm{CZ}$ and $7 \mathrm{C}$. We conclude, therefore, that in the range $15.0-26 \%$ protein, additional zein has a greater effect in reducing consumption than does casein, whereas in the range $26.0-38.0 \%$ these two proteins have comparable suppressive effects. In addition, assimilation 
Table 3. Performance of fifth-instar Spodoptera eridania larvae fed diets of different nitrogen content and composition

\begin{tabular}{|c|c|c|c|c|c|c|c|c|c|}
\hline \multirow[b]{2}{*}{ Diet* } & \multirow[b]{2}{*}{$n$} & \multicolumn{2}{|c|}{ Larval dry mass (mg) } & \multirow{2}{*}{$\begin{array}{l}\text { Instar } \\
\text { duration } \\
\text { (h) }\end{array}$} & \multicolumn{5}{|c|}{ Nutritional index } \\
\hline & & Initial & Final & & RGR† & RCR†t & AD $\ddagger$ & ECD & ECI \\
\hline $2 C$ & 21 & $\begin{array}{r}0.0090^{\mathrm{a}} \\
(0.0009)\end{array}$ & $\begin{array}{c}0.034^{\mathrm{a}} \\
(0.005)\end{array}$ & $\begin{array}{r}63.7^{2} \\
(5.6)\end{array}$ & $\begin{array}{c}0.438^{x} \\
(0.027)\end{array}$ & $\begin{array}{r}1.69^{\circ} \\
(0.14)\end{array}$ & $\begin{array}{r}0.484^{\#} \\
(0.028)\end{array}$ & $\begin{array}{c}0.538^{\mathrm{a}} \\
(0.020)\end{array}$ & $\begin{array}{c}0.261^{2} \\
(0.023)\end{array}$ \\
\hline $4 C$ & 18 & $\begin{array}{r}0.0084^{a} \\
(0.0012)\end{array}$ & $\begin{array}{r}0.034^{a} \\
(0.005)\end{array}$ & $\begin{array}{l}63.7^{\mathrm{a}} \\
(8.0)\end{array}$ & $\begin{array}{c}0.453^{4} \\
(0.029)\end{array}$ & $\begin{array}{c}1.45^{b} \\
(0.10)\end{array}$ & $\begin{array}{c}0.554^{b} \\
(0.025)\end{array}$ & $\begin{array}{c}0.564^{b} \\
(0.018)\end{array}$ & $\begin{array}{c}0.313^{b} \\
(0.017)\end{array}$ \\
\hline $4 \mathrm{CZ}$ & 21 & $\begin{array}{c}0.0088^{a} \\
(0.0012)\end{array}$ & $\begin{array}{c}0.029^{b} \\
(0.004)\end{array}$ & $\begin{array}{l}75.9^{\mathrm{h}} \\
(6.4)\end{array}$ & $\begin{array}{c}0.339^{6} \\
(0.027)\end{array}$ & $\begin{array}{r}1.21^{\circ} \\
(0.07)\end{array}$ & $\begin{array}{r}0.505^{2} \\
(0.017)\end{array}$ & $\begin{array}{c}0.554^{a b} \\
(0.023)\end{array}$ & $\begin{array}{r}0.280^{\circ} \\
(0.017)\end{array}$ \\
\hline $7 C$ & 18 & $\begin{array}{c}0.0087^{8} \\
(0.0007)\end{array}$ & $\begin{array}{c}0.027^{b} \\
(0.004)\end{array}$ & $\begin{array}{l}64.3^{\mathrm{a}} \\
(8.1)\end{array}$ & $\begin{array}{c}0.385^{c} \\
(0.038)\end{array}$ & $\begin{array}{r}1.14^{6} \\
(0.17)\end{array}$ & $\begin{array}{r}0.632^{d} \\
(0.031)\end{array}$ & $\begin{array}{c}0.543^{\mathrm{ab}} \\
(0.052)\end{array}$ & $\begin{array}{r}0.342^{\mathrm{d}} \\
(0.026)\end{array}$ \\
\hline $7 \mathrm{CZ}$ & 21 & $\begin{array}{c}0.0082^{\mathrm{a}} \\
(0.0012)\end{array}$ & $\begin{array}{c}0.028^{\mathrm{b}} \\
(0.004)\end{array}$ & $\begin{array}{l}66.1^{\mathrm{a}} \\
(5.4)\end{array}$ & $\begin{array}{c}0.395^{\circ} \\
(0.031)\end{array}$ & $\begin{array}{r}1.18^{c} \\
(0.11)\end{array}$ & $\begin{array}{c}0.581^{\mathrm{c}} \\
(0.012)\end{array}$ & $\begin{array}{c}0.577^{b} \\
(0.028)\end{array}$ & $\begin{array}{r}0.335^{d} \\
(0.014)\end{array}$ \\
\hline
\end{tabular}

Means are reported with standard deviations in parentheses. Means followed by different letters are significantly different at $P<0.05$ by Scheffe analysis.

$\mathrm{RGR}=$ relative growth rate; $\mathrm{RCR}=$ relative consumption rate; $\mathrm{AD}=$ assimilation efficiency; $\mathrm{ECD}=$ net growth efficiency; $\mathrm{ECI}=$ gross growth efficiency.

* Refer to Table I for composition of diet.

†Units: $\mathrm{mg} / \mathrm{mg}$ (dry mass)/day.

$\ddagger$ Because variances were unequal, the significance of pairwise comparisons was determined by Mann-Whitney $U$ tests with $\alpha$ set at 0.005 to adjust for multiple comparisons.

efficiency is lower for larvae on diets $4 \mathrm{CZ}$ and $7 \mathrm{CZ}$ than for larvae on diets $4 \mathrm{C}$ and $7 \mathrm{C}$, respectively, indicating that zein is significantly less digestible by $S$. eridania larvae than casein.

The values of relative growth rate that we have measured for fifth-instar southern armyworm larvae on artificial diets fall within the range of $0.3-0.5 \mathrm{mg} / \mathrm{mg} / \mathrm{day}$ reported for $S$. eridania larvae on a wide variety of woody and herbaceous plants (Scriber, 1984; Slansky and Scriber, 1985).

\section{The nitrogen budget}

The importance of quality and quantity of dietary protein is further clarified by a comparison of the nitrogen-based nutritional indices of fifth-instar larvae on diets $2 \mathrm{C}, 4 \mathrm{C}, 4 \mathrm{CZ}, 7 \mathrm{C}$ and $7 \mathrm{CZ}$ (Table 4). Relative nitrogen accumulation rate, like relative growth rate, is rather insensitive to variation in the quantity of dietary casein. Relative nitrogen accumulation rate varies only $20 \%$ between diets $2 \mathrm{C}, 4 \mathrm{C}$ and 7C. The replacement of a portion of the casein in the diet with zein has the same effect on this index that it has on relative growth rate. Relative nitrogen accumulation rate is more sensitive to protein quality than quantity on diets with protein contents in the range $15.0-26.0 \%$ protein (diets $2 \mathrm{C}, 4 \mathrm{C}$ and $4 \mathrm{CZ}$ ). When protein content is increased from $15.0 \%$ (diet $2 \mathrm{C}$ ) to $26.0 \%$ by the addition of more casein (to give diet $4 \mathrm{C}$ ), relative nitrogen accumulation rate increases by $16 \%$, whereas when the same increase in protein content is achieved by the addition of zein (to give diet $4 \mathrm{CZ}$ ), this index decreases by $13 \%$. As a consequence, relative nitrogen accumulation rate is $25 \%$ lower for larvae on diet $4 \mathrm{CZ}$ than for larvae on diet $4 \mathrm{C}$. In contrast, there are no significant differences in this index on diets $4 \mathrm{C}, 7 \mathrm{C}$ and $7 \mathrm{CZ}$, demonstrating that it is unaffected by changes in either protein quality or quantity on diets with protein contents in the range $26.0-38.0 \%$.

The effects of protein quality and quantity on relative nitrogen accumulation rate are further clarified by a consideration of the sensitivity of the individual indices of nitrogen utilization to the amount and composition of dietary protein. The relative consumption rate of nitrogen and the efficiency of conversion of digested nitrogen to tissue are sensitive to both the quantity and the quality of dietary nitrogen (Table 4). Overall, relative nitrogen

Table 4. Indices of nitrogen utilization by fifth-instar Spodoptera eridania larvae fed diets of different nitrogen content and composition. All values are corrected for storage and excretion of uric acid

\begin{tabular}{|c|c|c|c|c|c|c|}
\hline \multirow[b]{2}{*}{ Diet* } & \multirow[b]{2}{*}{$n$} & \multicolumn{5}{|c|}{ Nutritional index } \\
\hline & & RNAR + & $\mathbf{R C R}(\mathbf{N}) \dagger$ & $A D(N)$ & $\mathrm{ECD}(\mathrm{N})$ & $\mathrm{ECI}(\mathrm{N})$ \\
\hline $2 C$ & 7 & $\begin{array}{r}0.03 \mathrm{l}^{\mathrm{a}} \\
(0.002)\end{array}$ & $\begin{array}{r}0.044^{2} \\
(0.002)\end{array}$ & $\begin{array}{r}0.811^{2} \\
(0.015)\end{array}$ & $\begin{array}{r}0.859^{\circ} \\
(0.037)\end{array}$ & $\begin{array}{r}0.697^{\mathrm{A}} \\
(0.023)\end{array}$ \\
\hline $4 \mathrm{C}$ & 7 & $\begin{array}{r}0.036^{b} \\
(0.002)\end{array}$ & $\begin{array}{r}0.055^{b} \\
(0.003)\end{array}$ & $\begin{array}{r}0.814^{a} \\
(0.015)\end{array}$ & $\begin{array}{r}0.812^{\mathrm{b}} \\
(0.018)\end{array}$ & $\begin{array}{c}\left(0.0661^{\mathrm{a}}\right. \\
(0.023)\end{array}$ \\
\hline $4 C Z$ & 7 & $\begin{array}{r}0.027^{\circ} \\
(0.002)\end{array}$ & $\begin{array}{r}0.050^{\mathrm{c}} \\
(0.001)\end{array}$ & $\begin{array}{r}0.745^{b} \\
(0.031)\end{array}$ & $\begin{array}{r}0.730^{6} \\
(0.036)\end{array}$ & $\begin{array}{r}0.544^{b} \\
(0.026)\end{array}$ \\
\hline $7 \mathrm{C}$ & 6 & $\begin{array}{r}0.037^{b} \\
(0.003)\end{array}$ & $\begin{array}{c}0.060^{\mathrm{bd}} \\
(0.005)\end{array}$ & $\begin{array}{r}0.816^{2} \\
(0.013)\end{array}$ & $\begin{array}{r}0.750^{\circ} \\
(0.017)\end{array}$ & $\begin{array}{c}0.612^{\mathrm{c}} \\
(0.017)\end{array}$ \\
\hline $7 \mathrm{CZ}$ & 7 & $\begin{array}{r}0.038^{\circ} \\
(0.003)\end{array}$ & $\begin{array}{r}0.067^{6} \\
(0.005)\end{array}$ & $\begin{array}{r}0.780^{\circ} \\
(0.011)\end{array}$ & $\begin{array}{r}0.739^{\circ} \\
(0.029)\end{array}$ & $\begin{array}{c}0.576^{6 x} \\
(0.024)\end{array}$ \\
\hline
\end{tabular}

Means are reported with standard deviations in parentheses. Means followed by different letters are significantly different $P<0.05$ by Scheffe analysis.

RNAR = relative nitrogen accumulation rate; $R C R(N)=$ relative nitrogen consumption rate; $A D(N)=$ nitrogen assimilation efficiency; $E C D(N)=$ nitrogen conversion efficiency; $\mathrm{ECI}(\mathrm{N})=$ nitrogen utilization efficiency.

* Refer to Table 1 for composition of diet.

+Units: $\mathrm{mg} / \mathrm{mg}$ (dry mass)/day. 
Table 5. Nitrogen (N) budgets for fifth-instar Spodoptera eridania larvae fed diets of different nitrogen content and composition

\begin{tabular}{|c|c|c|c|c|c|c|c|c|}
\hline \multirow[b]{3}{*}{ Diet* } & \multirow[b]{3}{*}{$n$} & \multicolumn{7}{|c|}{ Amount (mg)/larva } \\
\hline & & \multirow{2}{*}{$\stackrel{\mathrm{N}}{\text { ingested }}$} & \multicolumn{2}{|c|}{$\mathbf{N}$ in faeces } & \multicolumn{2}{|c|}{$\mathbf{N}$ in carcass } & \multirow{2}{*}{$\begin{array}{l}\text { N not } \\
\text { accounted } \\
\text { for }\end{array}$} & \multirow{2}{*}{$\begin{array}{l}\text { Total UA } \\
\text { produced }\end{array}$} \\
\hline & & & UA & Non-UA & UA & Non-UA & & \\
\hline \multirow[t]{2}{*}{$2 \mathrm{C}$} & 7 & $7.57^{\mathrm{a}}$ & $0.073^{\text {ace }}$ & $1.43^{\mathrm{a}}$ & $0.148^{\circ}$ & $5.31^{\mathrm{a}}$ & 0.61 & $0.67^{2}$ \\
\hline & & $(0.44)$ & $(0.116)$ & $(0.15)$ & $(0.031)$ & $(0.36)$ & & $(0.37)$ \\
\hline \multirow[t]{2}{*}{$4 C$} & 7 & $7.85^{\mathrm{ab}}$ & $0.100^{\mathrm{a}}$ & $1.46^{\mathrm{ab}}$ & $0.120^{\mathrm{ab}}$ & $5.22^{\circ}$ & 0.95 & $0.66^{\mathrm{ac}}$ \\
\hline & & $(1.95)$ & $(0.051)$ & $(0.38)$ & $(0.075)$ & $(1.32)$ & & $(0.35)$ \\
\hline \multirow[t]{2}{*}{$4 C Z$} & 7 & $8.76^{\mathrm{ab}}$ & $0.592^{\mathrm{b}}$ & $2.26^{\mathrm{abcd}}$ & $0.269^{\mathrm{a}}$ & $4.81^{\circ}$ & 0.83 & $2.58^{b}$ \\
\hline & & $(1.92)$ & $(0.225)$ & $(0.66)$ & $(0.098)$ & (1.01) & & $(0.72)$ \\
\hline \multirow[t]{2}{*}{$7 \mathrm{C}$} & 6 & $9.62^{b}$ & $0.048^{\mathrm{gd}}$ & $1.77^{\mathrm{b}}$ & $0.126^{\mathrm{ab}}$ & $5.94^{\prime \prime}$ & 1.74 & $0.52^{x}$ \\
\hline & & $(0.91)$ & $(0.017)$ & $(0.17)$ & $(0.034)$ & $(0.70)$ & & $(0.07)$ \\
\hline \multirow[t]{2}{*}{$7 \mathrm{CZ}$} & 7 & $9.88^{b}$ & $0.408^{b}$ & $2.18^{\mathrm{c}}$ & $0.197^{a}$ & $5.74^{a}$ & 1.36 & $1.81^{\mathrm{bd}}$ \\
\hline & & $(0.53)$ & $(0.069)$ & $(0.16)$ & $(0.077)$ & $(0.35)$ & & $(0.37)$ \\
\hline \multirow[t]{2}{*}{$7 \mathrm{CE}$} & 6 & $9.02^{b}$ & $0.013^{\text {cd }}$ & $1.83^{\mathrm{abc}}$ & $0.070^{\mathrm{b}}$ & $6.01^{a}$ & 1.10 & $0.25^{\mathrm{c}}$ \\
\hline & & $(1.40)$ & $(0.016)$ & $(0.28)$ & $(0.024)$ & $(0.88)$ & & $(0.10)$ \\
\hline \multirow[t]{2}{*}{$7 \mathrm{CN}$} & 8 & $10.60^{b}$ & $0.282^{b c}$ & $3.65^{d}$ & $0.200^{\mathrm{a}}$ & $5.11^{\mathrm{a}}$ & 1.36 & $1.45^{\mathrm{d}}$ \\
\hline & & $(2.26)$ & $(0.088)$ & $(0.84)$ & $(0.064)$ & $(1.04)$ & & $(0.43)$ \\
\hline
\end{tabular}

Means are reported with standard deviation in parentheses. Means followed by different letters are significantly different at $P<0.05$ by Mann-Whitney $U$ tests with $\alpha$ set at $0.0025(0.05 / 20)$ to adjust for multiple comparisons. $\mathrm{UA}=$ uric acid

* Refer to Table I for composition of diet.

consumption rate increases as the nitrogen content of the diet increases, whether the increase is due to additional casein or zein. Moreover, this rate increases despite a decrease in relative consumption rate. Thus on high nitrogen diets, consumption rate is not reduced sufficiently to stabilize nitrogen intake. Relative nitrogen consumption rate is greater on diet $4 \mathrm{C}$ than on diet $4 \mathrm{CZ}$, indicating that for larvae on a diet containing $26.0 \%$ protein, consumption rate is also responsive to protein quality. Like relative nitrogen consumption rate, nitrogen conversion efficiency is sensitive to both nitrogen quantity and quality. On diets $2 \mathrm{C}, 4 \mathrm{C}$ and $7 \mathrm{C}$, nitrogen conversion efficiency decreases as casein content increases, whereas it is greater on diet $4 C$ than on diet $4 C Z$. In contrast, nitrogen assimilation efficiency is sensitive only to protein quality, and does not differ between diets $2 \mathrm{C}$, $4 \mathrm{C}$ and $7 \mathrm{C}$, but is higher on diets $4 \mathrm{C}$ and $7 \mathrm{C}$ than on $4 \mathrm{CZ}$ and $7 \mathrm{CZ}$, respectively. These relationships clearly reflect the lower nutritional value of zein compared to casein. Zein is consumed less rapidly, digested less efficiently, and the assimilated products of its digestion are converted into larval tissue less efficiently by $S$. eridania larvae.

\section{Uric acid production and the nitrogen budget}

The amount of uric acid produced by fifth-instar larvae is dependent upon the quality, but not on the quantity, of ingested nitrogen (Table 5). Larvae from diet $7 \mathrm{C}$ ingested $27 \%$ more nitrogen than larvae on diet $2 \mathrm{C}$, yet produced no more uric acid. However, larvae on diets $4 \mathrm{CZ}$ and $7 \mathrm{CZ}$ excreted more uric acid and stored more uric acid in their body tissues than larvae on diets $4 C$ and $7 C$, respectively, despite ingesting comparable quantities of nitrogen. Larvae on the zein-containing diets produced 3-4 times more uric acid than larvae on diets containing only casein. The production of larger amounts of uric acid by larvae on diets $4 \mathrm{CZ}$ and $7 \mathrm{CZ}$ is, of course, entirely consistent with the lower values of nitrogen conversion efficiency observed for the larvae on these diets.
The importance of nitrogen quality is also illustrated by comparing the amount of uric acid produced by larvae on a diet containing only casein (7C), with the amounts produced by larvae on diets containing casein plus the essential amino acid mixture (7CE), and casein plus the non-essential amino acid mixture $(7 \mathrm{CN})$. Larvae on diet 7CE produce less uric acid than larvae on diets $7 \mathrm{C}$, whereas larvae on diet $7 \mathrm{CN}$ produce more uric acid than larvae on diets $7 \mathrm{C}$.

Our results are consistent with those of Horie and Wantanabe (1983), who reported that $B$. mori larvae excrete much higher levels of uric acid when fed zein than when fed casein. However, in contrast to our findings with $S$. eridania, uric acid excretion in $B$. mori increases significantly when the casein content of the diet is increased from 25 to $30 \%$.

\section{Carcass composition}

Larval composition is dependent upon both nitrogen quantity and quality (Table 6). Increases in diet nitrogen content are paralleled by increases in both larval nitrogen content and soluble larval protein. The nitrogen and protein contents of larvae from the diet containing $26.0 \%$ protein $(4 \mathrm{C})$ were significantly higher than those of larvae from the comparable zein-containing diet $(4 \mathrm{CZ})$. No significant differences $(P<0.05)$ between lipid contents of larvae on the different diets could be detected using the Mann-Whitney $U$ test, with $\alpha$ set at 0.005 to adjust for 10 comparisons. However, had we restricted our analysis to the two diets most different in nitrogen quantity ( $2 \mathrm{C}$ vs $7 \mathrm{C}$ ) and the two diets most different in nitrogen quality (7C vs $7 \mathrm{CZ}$ ), both differences would have been marginally significant.

There is a highly significant negative correlation between larval lipid and protein content (Fig. 1). Larval lipid:nitrogen and lipid:protein ratios are, therefore, highly dependent upon both the quantity and quality of diet nitrogen. A similar influence of diet nitrogen on carcass lipid and nitrogen composition has been reported for larvae of the tortricid moth, Argyrotaenia velutinana (Lii et al., 1975). 
Table 6. Nitrogen, soluble protein, and extractable lipid contents of Spodoptera eridania larvae at the onset of the sixth-instar fed diets of different nitrogen content and composition

\begin{tabular}{|c|c|c|c|c|c|c|c|c|}
\hline \multirow[b]{3}{*}{$\operatorname{Diet}^{*}$} & \multicolumn{6}{|c|}{ Larval composition } & \multirow{2}{*}{\multicolumn{2}{|c|}{ Ratios }} \\
\hline & \multicolumn{2}{|c|}{ Nitrogen } & \multicolumn{2}{|c|}{ Protein } & \multicolumn{2}{|c|}{ Lipid } & & \\
\hline & $n$ & $\%$ & $n$ & $\%$ & $n$ & $\%$ & Lipid: Nitrogen & Lipid : Protein \\
\hline $2 \mathrm{C}$ & 7 & $\begin{array}{r}7.13^{2} \\
(0.21)\end{array}$ & 5 & $\begin{array}{l}13.8^{\text {B }} \\
(0.93)\end{array}$ & 3 & $\begin{array}{l}49.1^{8} \\
(7.64)\end{array}$ & 6.9 & 3.6 \\
\hline $4 \mathrm{C}$ & 7 & $\begin{array}{r}8.18^{6} \\
(0.07)\end{array}$ & 5 & $\begin{array}{l}17.1^{b} \\
(0.76)\end{array}$ & 5 & $\begin{array}{l}32.1^{2} \\
(9.49)\end{array}$ & 3.9 & 1.9 \\
\hline $4 C Z$ & 7 & $\begin{array}{r}7.76^{\mathrm{c}} \\
(0.18)\end{array}$ & 5 & $\begin{array}{l}13.5^{\mathrm{a}} \\
(0.94)\end{array}$ & 1 & $61.4^{\mathrm{a}}$ & 7.9 & 4.5 \\
\hline $7 \mathrm{C}$ & 6 & $\begin{array}{r}9.75^{d} \\
(0.21)\end{array}$ & 6 & $\begin{array}{l}24.8^{c} \\
(6.5)\end{array}$ & 4 & $\begin{array}{r}17.3^{a} \\
(10.6)\end{array}$ & 1.8 & 0.70 \\
\hline $7 \mathrm{CZ}$ & 7 & $\begin{array}{r}9.54^{d} \\
(0.22)\end{array}$ & 6 & $\begin{array}{l}20.2^{c} \\
(0.45)\end{array}$ & 6 & $\begin{array}{l}34.0^{3} \\
(7.42)\end{array}$ & 3.6 & 1.7 \\
\hline
\end{tabular}

Means are reported with standard deviations in parentheses. Means followed by different letters are significantly different by Mann-Whitney $U$ tests with $\alpha$ set at $0.005(0.05 / 10)$ to adjust for multiple comparisons.

* Refer to Table 1 for composition of diet.

\section{Respiration rates}

Larval respiration rate is dependent upon the quality, but not the quantity, of ingested nitrogen (Table 7). An analysis of covariance, comparing the regressions of the natural logarithm of respiration rate against the natural logarithm of larval dry mass on each diet, reveals that the slopes of the six regressions are not significantly different, but that the intercepts are significantly higher for the larvae on diets $4 \mathrm{CZ}, 7 \mathrm{CZ}$ and $7 \mathrm{CN}$ than for the larvae on diets $2 \mathrm{C}, 4 \mathrm{C}$ and $7 \mathrm{C}$. Thus, at any given size, larvae on a zein-containing diet respire at a substantially higher rate than larvae of equal size on a diet containing only casein. From the regression equations, it is possible to calculate that a $10-\mathrm{mg}$ (dry mass) larva respires, on average, at a rate $26 \%$ higher on diet $4 \mathrm{CZ}$ than on diet $4 C$, and 96 and $92 \%$ higher on diets $7 \mathrm{CZ}$ and $7 \mathrm{CN}$, respectively, than on diet $7 \mathrm{C}$.

\section{DISCUSSION}

\section{Larval growth as a function of diet nitrogen.}

$S$. eridania larvae possess an impressive capacity to maintain their growth rates within a fairly narrow range on artificial diets containing a wide range of casein concentrations. Relative growth rate and relative nitrogen accumulation rate vary less than $20 \%$ on diets in which protein content varies more than $250 \%$. The relative independence of growth and nitrogen accumulation rates of $S$. eridania larvae on artificial diets containing very different amounts of casein is a consequence of adjustments in consumption rates and changes in efficiencies of food utilization. In addition, at high levels of dietary protein, $S$. eridania larvae are capable of stabilizing relative growth rate and relative nitrogen accumulation rate in the face of considerable variation in the quality of dietary protein.

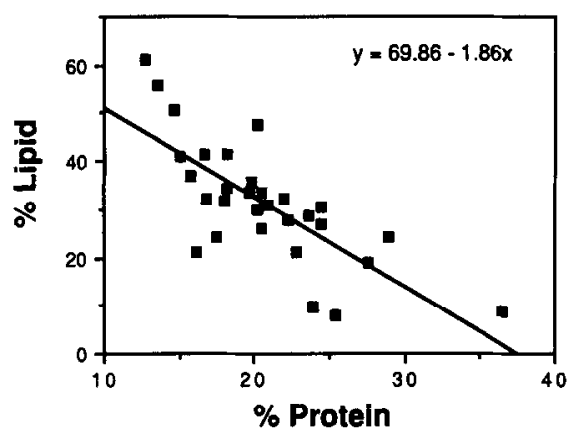

Fig. 1. Lipid content of Spodoptera eridania larvae at onset of sixth instar as a function of larval protein content. Regression equation for \% lipid against \% protein is $y=-1.86 x+69.86\left(r^{2}=0.56, \quad P<0.0001, n=30\right)$ for larvae from diets $2 \mathrm{C}, 4 \mathrm{C}, 4 \mathrm{CZ}, 7 \mathrm{C}, 7 \mathrm{CZ}, 7 \mathrm{CE}$ and $7 \mathrm{CN}$.

Table 7. Respiration rates $(v)$ of fifth-instar Spodoptera eridania larvae fed diets of different nitrogen content and composition

\begin{tabular}{|c|c|c|c|c|c|c|c|}
\hline \multirow[b]{3}{*}{$\operatorname{Diet}^{*}$} & \multirow[b]{3}{*}{$n$} & \multicolumn{4}{|c|}{ Regression parameters } & \multirow{2}{*}{\multicolumn{2}{|c|}{$\begin{array}{l}\text { Respiration rate } \\
\left(\mu 1 \mathrm{O}_{2} / \mathrm{h} \text { ) for } 10-\mathrm{mg}\right. \\
\text { (dry mass) larva }\end{array}$}} \\
\hline & & & & & Significance & & \\
\hline & & Slope & Intercept & $r^{2}$ & of regression & $\ln v$ & $\boldsymbol{v}$ \\
\hline $2 C$ & 51 & $0.83^{a}$ & $2.12^{\mathrm{a}}$ & 0.45 & $<0.0001$ & $4.03(0.112)$ & 56.4 \\
\hline $4 C$ & 78 & $1.01^{a}$ & $1.64^{a}$ & 0.52 & $<0.0001$ & $3.79(0.088)$ & 52.9 \\
\hline $4 \mathrm{CZ}$ & 16 & $0.37^{\mathrm{a}}$ & $3.35^{\mathrm{b}}$ & 0.23 & 0.0612 & $4.20(0.146)$ & 66.8 \\
\hline $7 \mathrm{C}$ & 33 & $1.11^{\mathrm{a}}$ & $1.30^{\mathrm{a}}$ & 0.61 & $<0.0001$ & $3.87(0.115)$ & 47.7 \\
\hline $7 \mathrm{CZ}$ & 19 & $0.89^{\mathrm{a}}$ & $2.48^{\mathrm{a}}$ & 0.83 & $<0.0001$ & $4.54(0.098)$ & 93.7 \\
\hline $7 \mathrm{CN}$ & 9 & $0.59^{8}$ & $3.16^{\mathrm{B}}$ & 0.56 & 0.0205 & $4.52(0.192)$ & 91.4 \\
\hline
\end{tabular}

Values for the slopes and intercepts of the regressions of In respiration rate $\left(\mu \mid O_{2} / \mathrm{h}\right)$ vs ln larval dry mass (mg) followed by different letters are significantly different at $P<0.05$ by analysis of covariance. Values for respiration rate with $95 \%$ confidence limits in parentheses, for a 10 -mg (dry mass) larva were calculated from the regression equations.

* Refer to Table 1 for composition of diet. 
Whereas the relative insensitivity of the growth rate of $S$. eridania larvae to diet quality may be impressive, growth rates do, nonetheless, vary significantly in response to changes in the quantity and quality of diet nitrogen. It seems very likely that differences in relative growth rate observed for fifth-instar larvae on the different diets would be maintained or even amplified during the final instar, yeilding even larger differences in pupal weights. Since fecundity is often positively correlated with pupal weight in Lepidoptera (Courtney, 1981; Hinton, 1981; Renwick and Radke, 1982; Karowe, 1988), both the quantity and quality of diet protein are likely to be important determinants of fitness in $S$. eridania.

In addition, larval composition is highly dependent upon both the quantity and quality of ingested nitrogen. Larvae from diets low in nitrogen or containing nutritionally unbalanced protein consist of more fat and less protein than larvae from diets high in nitrogen or containing nutritionally balanced proteins. While we cannot say which lipid:protein ratio maximizes fitness, it is undoubtedly true that fitness is influenced by larval composition. Thus, even the capacity to maintain a larval growth rate that is relatively independent of diet quality does not necessarily imply that fitness is independent of diet quality.

\section{Metabolic rate as a function of diet nitrogen}

Larvae on a diet containing $32.6 \%$ casein (diet 7C) produce no more uric acid and respire at no higher a rate than larvae on a diet containing only $7.5 \%$ casein (diet 2C). Thus, the high levels of dietary casein do not impose a detectable metabolic load on $S$. eridania larvae. The modest reduction in relative growth rate of the larvae on the high-casein diet is a consequence of reduced consumption, not increased metabolic costs.

In contrast, the presence of zein in the diet does impose a metabolic load on the larvae. Larvae on the zein-containing diets (diets $4 \mathrm{CZ}$ and $7 \mathrm{CZ}$ ) produce significantly more uric acid and respire at significantly higher rates than larvae on diets with the same total protein content, but containing only casein (diets $4 \mathrm{C}$ and $7 \mathrm{C}$ ). Thus, there is a measurable metabolic cost associated with processing low quality protein, and this cost can be attributed, at least in part, to the elimination of a nitrogen surplus by the synthesis and excretion of uric acid. It is important to note, however, that despite the higher cost of processing diet $7 \mathrm{CZ}$ than diet $7 \mathrm{C}$, larvae on diet $7 \mathrm{CZ}$ grow as fast, accumulate nitrogen as efficiently, attain the same final weight, and convert digested food into larval tissue as efficiently as larvae on diet $7 \mathrm{C}$. Thus, the existence of a food processing cost does not necessarily result in a reduction in growth rate or growth efficiency. Even when there is a detectable food processing cost and a reduction in growth, as for larvae on diet $4 \mathrm{CZ}$ relative to larvae on diet $4 \mathrm{C}$, there is no basis for concluding that the elevated metabolic rate is the cause of the reduced growth rate. Indeed, net growth efficiency of larvae on diet $4 \mathrm{CZ}$ is not significantly different from that of larvae on diet $4 \mathrm{C}$. On the other hand, relative consumption rate, relative nitrogen consumption rate, assimilation efficiency, nitrogen assimilation efficiency, and nitrogen conver- sion efficiency are all significantly lower for larvae on the zein-containing diet. Clearly, reduced growth on diet $4 \mathrm{CZ}$ is due to the reduced palatability, lower digestibility, and less favourable amino acid composition of zein compared to casein, not to a higher metabolic cost associated with the processing of zein.

The idea that growth rates on sub-optimal diets may be reduced because of increased metabolic processing costs is gaining currency in the field of nutritional ecology (Scriber, 1977, 1979, 1981; Schoonhoven and Meerman, 1978; Brattsten, 1979; Scriber and Feeny, 1979; Slansky and Scriber, 1985). As appealing and plausible as the idea may seem, it should be viewed with considerable caution, since it is based upon the dubious assumption that growth by insect folivores is energy-limited. In fact, it is generally believed that herbivore growth is not limited by energy, but instead, by nitrogen (Southwood, 1973; Slansky and Feeny, 1977; Schroeder, 1981) or water (Schroeder, 1986; Martin and Van't Hof, 1988). Thus, we are inclined to agree with Slansky and Feeny (1977) that "Energy, present in superabundant supply, is unlikely to affect growth rates, and energy efficiencies are thus likely to be consequence rather than causes of growth performance".

\section{Diet nitrogen and the evolution of specialization in} insect herbivores

There seems little doubt that nutritionally unbalanced foliar proteins could constitute a general 'barrier' to herbivory. What is less clear is whether nutritionally unbalanced foliar proteins would select for host-plant specialization among insect herbivores. The extent to which selection would favour specialization depends on at least four factors: (1) the extent of genetic variation in amino acid requirements within herbivore populations; (2) the extent to which variation in amino acid profiles between host plant species exceeds that within host plant species; (3) whether herbivore adaptations that maximize the uptake of the growth-limiting amino acid from one host plant necessarily result in trade-offs that preclude simultaneous maximization of uptake of the same or a different amino acid from a different host plant; and (4) whether herbivore growth on any particular host plant is limited by carbon (e.g. energy), nitrogen (e.g. a specific amino acid), water, or some other nutrient.

If growth is energy-limited, then selection should favour energy efficiency, particularly in those processes that carry high energetic costs. This study has demonstrated that the processing of nutritionally unbalanced protcins results in a substantial metabolic cost, attributable at least in part to the conversion and excretion of excess nitrogen. On any given host plant, this cost will be minimal for herbivore genotypes requiring amino acids in the same proportions found in the host plant. To the extent that two host plant species differ consistently in their amino acid profiles, a given herbivore geneotype will not be able to maximize fitness on both species simultaneously. Thus, under the condition of energy-limitation, which is probably rare in folivores, nutritionally unbalanced foliar proteins may not only constitute a general 'barrier' to herbivory, but may also sclect for specialization among insect herbivores. 
It is more difficult to predict whether nutritionally unbalanced proteins would select for host plant specialization when growth is nutrient-limited, which is probably the more normal situation for most folivores. If growth is nitrogen-limited, then selection should strongly favour adaptations that enhance the extraction and conservation of those amino acids that limit growth at various stages of larval development, even if those adaptations are energetically costly. An adaptation that increased the fitness of an herbivore on one host by enhancing the uptake of a particular suite of potentially growth-limiting amino acids from that host could have a positive, neutral or negative effect on fitness on another host. The effect would be positive if the same amino acids were present in limiting quantities in the second host. The effect would be negative if different amino acids were limiting in the second host, and the adaptations that increased uptake of limiting amino acids from the first host reduced uptake of the different set of limiting amino acids from the second host. The effect would be neutral if growth were limited by different amino acids in the two hosts, and adaptations that increased uptake from one host had no adverse impact on uptake from the other. Our knowledge of the amino acid requirements of insect herbivores, the extent of variation in amino acid profiles in foliage, and the specificities of the carrier proteins involved in amino acid uptake is insufficient at the present time to permit informed speculation on these possibilities. Suffice it to say that nutritionally unbalanced foliar proteins could select for specialization among herbivors. We believe that an experimental approach to testing that possibility is feasible and would be an important contribution to understanding the evolutionary ecology of insect herbivores.

Acknowledgements - We thank the National Science Foundation for a grant (BSR-8421268) to M.M.M., which supported this research. We are grateful to William Fisher (FMC Corporation) for providing $S$. eridania eggs, Joan Martin for developing the artificial diet, Kelly Hester for assistance in uric acid analyses, Jan Cassin for conducting the protein and lipid analyses, and Heidi Van't Hof for conducting some of the statistical analyses and for preparing the figure.

\section{REFERENCES}

Autret M. (1970) Amino-Acid Content of Foods and Biological Data on Proteins. FAO United Nations, Rome. Bhattacharya A. K. and Waldbauer G. P. (1969) Quantitative determination of uric acid in insect feces by lithium carbonate extraction and the enzymatic-spectrophotometric method. Ann. ent. Soc. Am. 62, 925-927.

Bradford M. M. (1976) A rapid and sensitive method for the quantitation of microgram quantities of protein utilizing the principle of protein-binding. Analyt. Biochem. 72, 248-254.

Brattsten L. B. (1979) Biochemical defense mechanisms in herbivores against plant allelochemicals. In Herbivores: Their Interaction with Secondary Plant Metabolites (Edited by Rosenthal G. A. and Janzen D. H.), pp. 200-270. Academic Press, New York.

Brewer J. W., Capinera J. L., Deshon R. E. Jr and Walmsley M. L. (1985) Influence of foliar nitrogen levels on survival, development and reproduction of western spruce budworm, Choristoneura occidentalis (Lepidoptera: Tortricidae). Can. Ent. 117, 23-32.
Briegel H. (1985) Mosquito reproduction: incomplete utilization of the blood meal protein for oogenesis. $J$. Insect Physiol. 31, 15-21.

Broadway R. M. and Duffey S. S. (1986) The effect of dietary protein on the growth and digestive physiology of larval Heliothis zea and Spodoptera exigua. J. Insect Physiol. 32, 673-680.

Carter C. I. and Cole J. (1977) Flight regulation in the green spruce aphid (Elatobium abietinum). Ann. appl. Biol. 86, 137-151.

Courtney S. P. (1981) Coevolution of pierid butterflies and their cruciferous foodplants. III. Anthocaris cardamines (L.). Survival, development and reproduction on different hostplants. Oecologia 51, 91-96.

Dadd R. H. and Krieger D. L. (1968) Dietary amino acid requirements of the aphid, Myzus persicae. J. Insect Physiol. 14, 741-746.

van Emden H. F. (1972) Aphids as phytochemists. In Phytochemical Ecology (Edited by Harborne J.), pp. 25-43. Academic Press, London.

Hare J. D. (1983) Seasonal variation in plant-insect associations: utilization of Solanum dulcamara by Leptinotarsa decimlineata. Ecology 64, 345-361.

Hinton H. E. (1981) The Biology of Insect Eggs. Pergamon Press, Oxford.

Horie Y. and Inokuchi T. (1978) Protein synthesis and uric acid excretion in the absence of essential amino acids in the silkworm, Bombyx mori. Insect Biochem. 8, 251-254.

Horie Y. and Watanabe K. (1983) Effect of various kinds of dietary protein and supplementation with limiting amino acids on growth, haemolymph components and uric acid excretion in the silkworm, Bombyx mori. J. Insect Physiol. 29, 187-199.

Jansson R. K. and Smilowitz A. (1985) Influence of nitrogen on population parameters of potato insects: abundance, development, and damage of the Colorado potato beetle, Leptinotarsa decimlineata (Coleoptera: Chrysomelidae) Environ. Ent. 14, 500-506.

Karowe D. N. (1988) Ecological and evolutionary determinants of larval host plant range in the sulfur butterflies, Colias philodice and Colias interior. Ph.D. Dissertation, University of Michigan, Ann Arbor, Mich.

Lee J. A., McNeill S. and Rorison I. H. (1983) Nitrogen as an Ecological Factor, 22nd Symp. Br. Ecol. Soc. Blackwell, Oxford.

Lii G. Y., Garlich J. D. and Rock, G. C. (1975) Protein and energy utilization by the insect, Argyrotaenia velutinana (Walker), fed diets containing graded levels of an amino acid mixture. Comp. Biochem. Physiol. 52A, 615-618.

McNeill S. and Southwood T. R. E. (1978) The role of nitrogen in the development of insect plant relationships. In Biochemical Aspects of Plant and Animal Coevolution (Edited by Harborne J.), pp. 77-98. Academic Press, London.

Martin M. M. and Van't Hof H. M. (1988) The cause of reduced growth of Manduca sexta larvae on a low-water diet: increased metabolic processing costs or nutrient limitation? J. Insect Physiol. 34, 515-525.

Mattson W. J. (1980) Herbivory in relation to plant nitrogen content. Ann. Rev. Ecol. Syst. 11, 119-161.

Neter J., Wasserman W. and Kutner M. H. (1985) Applied Linear Statistical Models, 2nd edn. Irwin, Homewood, Ill.

Renwick J. A. and Radke C. D. (1982) Ovipositional choice and larval survival of the spruce budworm, Choristoneura fumiferana (Lepidoptera: Tortricidae). Environ. Ent. 11, 503-505.

Retnakaran A. and Beck S. D. (1968) Amino acid requirements and sulfur amino acid metabolism in the pea aphid Acyrthosiphon pisum (Harris). Comp. Biochem. Physiol. 24, 611-619.

Rodriguez J. G., Chaplin C. E., Stoltz L. P. and Lasheen A. M. (1970) Studies on resistance of strawberries to mites: I. Effects of plant nitrogen. J. Econ. Ent. 65, 50-53. 
Schoonhoven L. M. and Meerman J. (1978) Metabolic cost of changes in diet and neutralization of allelochemics. Ent. exp. appl. 24, 689-693.

Schroeder L. A. (1981) Consumer growth efficiencies: their limits and relationships to ecological processes. J. Theor Biol. 93, 805-828.

Schroeder L. A. (1986) Protein limitations of a tree feeding Lepidopteran. Ent. exp. appl. 41, 115-120.

Schroeder L. A. and Malmer M. (1980) Dry matter, energy and nitrogen conversion by Lepidoptera and Hymenoptera larvae fed leaves of black cherry. Oecologia 45, 63-71.

Scriber J. M. (1977) Limiting effects of low leaf-water content on the nitrogen utilization, energy budget, and larval growth of Hyalophora cecropia (Lepidoptera: Saturniidae). Oecologia 28, 269-287.

Scriber J. M. (1979) Post-ingestive utilization of plant biomass and nitrogen by Lepidoptera: legume feeding by the southern armyworm. J. N.Y. Ent. Soc. 87, 141-153.

Scriber J. M. (1981) Sequential diets, metabolic costs, and growth of Spodoptera eridania (Lepidoptera: Noctuidae) feeding upon dill, lima bean, and cabbage. Oecologia 51, 175180.

Scriber J. M. (1984) Host plant suitability. In Chemical Ecology of Insects (Edited by Bell W. and Cardé R. T.), pp. 159-202. Chapman \& Hall, London.

Scriber J. M. and Feeny P. P. (1979) Growth of herbivorous caterpillars in relation to feeding specialization and growth form of their foodplants. Ecology 60, 829-850.

Slansky F. Jr and Feeny P. (1977) Stabilization of the rate of nitrogen accumulation by larvae of the cabbage but- terfly on wild and cultivated food plants. Ecol. Monog. 47, 209-228.

Slansky F. Jr and Scriber J. M. (1985) Food consumption and utilization. In Comparative Insect Physiology Biochemistry and Pharmacology (Edited by Kerkut G. A. and Gilbert L. I.), Vol. 4, pp. 87-163. Pergamon Press, Oxford.

Sokal R. R. and Rohlf F. J. (1981) Biometry, 2nd edn. Freeman, San Francisco.

Soo Hoo C. F. and Fraenkel G. (1966) The consumption and utilization of food plants by a polyphagous insect, Prodenia eridania (Cramer). I. Insect Physiol. 12, 711-730.

Southwood T. R. E. (1973) The insect/plant relationshipan evolutionary perspective. Symp. R. Ent. Soc. Lond. 6, 3-30.

Waldbauer G. P. (1968) The consumption and utilization of food by insects. Adv. Insect Physiol. 5, 229288.

Watson L. and Creaser E. H. (1975) Non-random variation of protein amino-acid profiles in grass seeds and dicot leaves. Phytochemistry 14, 1211-1217.

Yeoh H.-Y. and Watson L. (1982) Taxonomic variation in total leaf protein amino acid composition of grasses. Phytochemistry 21, 615-626.

Yeoh H.-Y., Wee Y. C. and Watson L. (1984) Systematic variation in leaf amino acid compositions of leguminous plants. Phytochemistry 23, 2227-2229.

Yeoh H.-Y., Wee Y. C. and Watson L. (1986) Taxonomic variation in total leaf protein amino acid compostions of monocotyledenous plants. Biochem. Syst. Ecol. 14, 91-96. 